\title{
Distinguishing Quaternary glyptodontine cingulates in South America: How informative are juvenile specimens?
}

Carlos A. Luna, Ignacio A. Cerda, Alfredo E. Zurita, Romina Gonzalez, M. Cecilia Prieto, Dimila Mothé, and Leonardo S. Avilla

Acta Palaeontologica Polonica 63 (1), 2018: 159-170 doi:https://doi.org/10.4202/app.00409.2017

The subfamily Glyptodontinae (Xenarthra, Cingulata) comprises one of the most frequently recorded glyptodontids in South America. Recently, the North American genus Glyptotherium was recorded in South America, in addition to the genus Glyptodon. It has been shown that both genera shared the same geographic distribution in central-north and eastern areas of South America (Venezuela and Brazil, respectively). Although some characters allow differentiation between adult specimens of both genera, the morphological distinction between these two genera is rather difficult in juvenile specimens. In this contribution, a detailed morphological, morphometric and histological survey of a juvenile specimen of Glyptodontinae recovered from the Late Pleistocene of northern Brazil is performed. The relative lower osteoderms thickness, the particular morphology of the annular and radial sulci and the distal osseous projections of the caudal osteoderms suggest that the specimen belongs to the genus Glyptotherium. In addition, the validity of some statistical tools to distinguish between different ontogenetic stages and in some cases between genera is verified. The osteoderm microstructure of this juvenile individual is characterized by being composed of a cancellous internal core surrounded by a compact bone cortex. Primary bone tissue mostly consists of highly vascularized, woven-fibered bone tissue. Unlike that observed in adult Glyptodontinae, both the Sharpey fibers and the fibrous and laminar parallel bone tissue as secondary bone are absent. This study enhances our knowledge about those morphological and histological changes that occur through the ontogeny in glyptodonts.

Key words: Mammalia, Cingulata, Glyptodontinae, osteoderm histology, ontogeny, Pleistocene, South America.

Carlos A. Luna [carlosaluna@hotmail.com], Alfredo E. Zurita [aezurita74@yahoo.com.ar

], and Romina Gonzalez [romigonz195@gmail.com], Centro de Ecología Aplicada del Litoral (CECOAL), CONICET-UNNE, Ruta 5, km 2.5, CC

128, (3400) Corrientes, Argentina. Ignacio A. Cerda [nachocerda6@yahoo.com.ar

], Universidad Nacional de Río Negro, CONICET, Instituto de

Investigaciones en Paleobiología y Geología, Museo Provincial "Carlos 
Ameghino", Belgrano 1700, Paraje Pichi Ruca (predio Marabunta),

CP8300 Cipolletti, Río Negro, Argentina. M. Cecilia Prieto [prietomariacecilia@gmail.com

], Facultad de Ciencias Agropecuarias (UNC), IMBIV-CONICET, Ing. Agr. Felix

A. Marrone 746, 5000 Córdoba, Argentina. Dimila Mothé [dimothe@ hotmail.com

] and Leonardo S. Avilla [leonardo.avilla@gmail.com], Laboratório de Mastozoologia, Departamento de Zoologia, Instituto de Biociências, Universidade Federal do Estado do Rio de Janeiro, Av. Pasteur, 458, 501, Urca, CEP 22290-240, Rio de Janeiro, Brazil; and Programa de Pós-graduação em Biodiversidade Neotropical, Instituto de Biociências, Universidade Federal do Estado do Rio de Janeiro, Av. Pasteur, 458, 501, Urca, CEP 22290-240, Rio de Janeiro, Brazil.

This is an open-access article distributed under the terms of the Creative Commons

Attribution License (for details please see creativecommons.org), which permits unrestricted use, distribution, and reproduction in any medium, provided the original author and source are credited.

Fafif Full text $(706.0 \mathrm{kB})$ 